\title{
Psalm 55 Interpreted in View of its Textual, Metatextual and Intertextual Connections*
}

\author{
Phil J. Botha \\ Department of Ancient Languages and Cultures, University of Pretoria, \\ University of Pretoria, Hatfield Campus, Lynwood Road, Hatfield, Pretoria, \\ 0002 \\ phil.botha@up.ac.za
}

\begin{abstract}
Psalms 52-55 constitute a cluster of psalms with significant links to one another, to Proverbs, and also to the history of David. Psalms 52 and 55 were both also influenced by motifs from Jer 9. These features point to their having been composed (Ps 52) or edited (Ps 55) with a specific focus in mind. This article attempts to read Psalm 55 on its own, but also within the context of the cluster and in its relationship to Jer 9 as well as David's history in order to refine our knowledge of the problems, values, hopes and expectations of the Persian period editors who compiled and edited the cluster.
\end{abstract}

Keywords: Psalm 55, Psalm 52, Jeremiah 9, David, 1 Samuel.

\section{Introduction}

Psalm 55 is often interpreted primarily from the point of view that it is an exilic or post-exilic individual lament with disputed unity. ${ }^{1}$ Yet, the designation of the psalm as a משכיל in Ps 55,1 (all verse numbers refer to the Hebrew Text, offset by one figure from some English translations) implies that the

\footnotetext{
* This work was supported by the National Research Foundation of South Africa under Grant No 85806. Opinions expressed and conclusions arrived at in this article are those of the author and not necessarily to be attributed to the NRF.

1. Terrien: 2003, 427 suggests that the repetition of conflicting themes could point to an origin of the psalm among Judean exiles in Lower Mesopotamia. Seybold: 1996, 222 locates it, together with its broader context group (52-59) "presumably" in the post-exilic time. He describes it as a "Klagepsalm eines einzelnen" which was possibly later on framed by prayers in 55,2-3 and 24. Hossfeld \& Zenger: 2002, p. 347 descibe it as "ein Klage- und Bittgebet eines Einzelnen." Weber: 2001, p. 247 calls it a "Klagegebet eines Einzelnen (oder eines Königs)." The mentioning of a group of enemies or, respectively, a single intimate friend who turned into an archenemy, has given occasion for literary critical doubts about its composition. Seybold: 1996, p. 222, considers the possibility that the two "Freundklagestrophen" 55,13-15 and 2123 could have a secondary origin, but says that it is impossible to be certain. Lament and prayer do, however, represent two different phases of origin or recital in his view.
} 
late post-exilic editors intended the psalm to be understood as the "teaching" or "instruction" of David and that it should be interpreted in the first place within the literary context of the cluster of psalms consisting of Pss 52-55 (all of which have this designation), and in the second place in view of the experiences of the literary figure of David as these are described in 1 and 2 Samuel.

The cluster as context of interpretation was "prescribed" by the editors ${ }^{3}$ not only by designating each member as a "Maskil," but also by inserting concatenating links between them with the help of keywords. ${ }^{4}$ They seem to have gone to great lengths to encourage the reader not to read these psalms in isolation. Two members of this group (52 and 54) each also have a biographical note connecting them more intimately to the life of David. Psalms 53 and 55, which do not have the biographical note, have similar connections with the history of David as it is described in Samuel, strengthening the surmise about the intention of the editors that they should be interpreted also within this literary context. ${ }^{5}$ Because of the density and pattern of presence of bio-

2. This designation is used in the headings of Pss $32 ; 42 ; 44 ; 45 ; 52-55 ; 74 ; 78 ; 88$; 89 and 142. If this is a term derived from the hiphil participle of שכל שכלך, it probably refers to "instruction to make wise." Ps 32,8 ("I will instruct you [אשכילך] and teach you in the way you should go") provides a good idea of its meaning, despite the fact that Köhler and Baumgartner state that it is uncertain whether משכיל is a technical term for a kind of "cult song," "memory passage" or a wisdom song performed to

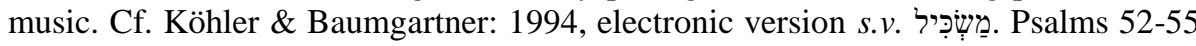
form the only cluster of Maskils.

3. Weber: 2014, pp. 284-304, has made an important contribution towards the understanding of the impact of the psalm headings by describing them as "Metatexts": "Es handelt sich bei ihnen um Texte sui generis, nämlich um Metatexte, die multiple Einund Zuordnungen markieren und aktivieren." He distinguishes between connections of a heading with its reference (the institution, performance, etc.) and on the level of intertext (established, authoritative literature, especially the books of Samuel), paratext (the surrounding psalms) and the text of the psalm itself.

4. Pss 52-54 in fact only form a sub-group of a larger ensemble of which Pss 56-60 constitute a second sub-group. Each one in that cluster is described as a "Miktam." The last one of this second sub-group, Ps 60, is described as "A Miktam of David; to instruct," with למד in the piel infinitive construct ("to instruct") having a meaning close to that of the designation משכיל. There are also keyword connections uniting the two sub-groups. Weber: 2014, p. 298, remarks that the "Zweckangabe" "um zu lehren" in Ps 60 strengthens the didactic colouring of Pss 52-59 at the end of the group and that it transforms the character of the psalm from communal lament (secondarily) into teaching.

5. The connections between Ps 53 and the history of David are discussed in Botha: 2013, pp. 583-606, cf. especially pp. 587, pp. 598-601. For example, it was Saul who was "rejected" (מאס) by Yahweh (Ps 53,7, 1 Sam 15,23 and 26; 16,1); it is he who "encamped" (חנה) against David (Ps 53,6; 1 Sam 26,3); and it is his "bones" (together with those of his sons) which were buried under a tamarisk tree (Ps 53,6; 1 Sam 31,913) before eventually being restored by David to the family grave (2 Sam 21,12-14), 
graphical notes in the headings in Pss 52-59 $(+-+-\mid++-++)$, Beat Weber calls Pss 52-59 a "Saul-David-Midrash."

All these features together suggest that Pss 53 and 55 were also meant to be visualized (like 52 and 54) as wise "instruction"7 which David abstracted from his interaction with enemies and with Yahweh and which he graciously bequeathed to later generations of righteous people. ${ }^{8}$ The connection with David was probably made because he seemed to the editors to be an ideal example of how the righteous people of their day and time had to respond to the enmity of fellow Israelites. He had the necessary wisdom to achieve success, because Yahweh was with him. ${ }^{9}$ They did not use only "David" to address their problems in this way, but sought help from other figures from the past as well. All the psalms in this cluster have wisdom connections, while it seems that Pss 52 and 55 were strongly influenced also by Jer $9 .{ }^{10}$ Similar to "David," "Jeremiah" also was an idealized and authoritative symbol of piety who suffered unjust persecution and it must have seemed acceptable to the editors of the Psalter to allude to Jer 9 to contextualise the enmity and tribulation to which they and their fellow believers were subjected. ${ }^{11}$

Psalm 55 has links with all the other members of the cluster but the first and last psalms of this small group have an even closer relationship. There are more keywords connecting those two and both also have clear connections with Jer 9. The links with Jer 9 are, in my view, significant. In the case of Ps 52, it is clear that the author of the psalm was influenced by Jer 9. The

so that they could be described as having been "scattered" (cf. Ps 53,6). For the connections of Ps 55 with the stories about David, see below.

6. In contradistinction to the "David-Absalom-Midrash" in Pss 3-7. Cf. Weber: 2014, 290, pp. 295-297.

7. Ps 52 is taken up almost completely by a wisdom diatribe against a powerful, rich, and evil opponent. Only the last verse can be described as a prayer. Ps 53 (an adapted version of Ps 14, reshaped for this context) is a meditation on corrupt evildoers who have abandoned "understanding" of God. Only the last verse is a wish that God will intervene. Pss 54 and 55 can be described as prayers about enemies (cf. תפלה, 54,4; 55,2 ), although Ps 55,14 does contain a direct address to the friend who turned out to be a deadly enemy.

8. Weber points out that Ps 34 , which has no designation of Gattung, but contains a biographical note directing the reader to the time of David's flight from Saul, similarly serves a teaching function. Cf. Weber: 2014, p. 297. In Ps 34,12 "David" says, "Come, children, listen to me; I will teach (למד piel) you the fear of Yahweh."

9. 1 Sam 18,14, "And David had success (ויהי משכיל) in all his undertakings, for Yahweh was with him." Yahweh's presence with David is stressed through repetition in 1 Samuel (cf. also 1 Sam 16,18; 18,12.28).

10. The connections between Jer 9 and Ps 52 are discussed in Botha: 2013. The influence of Jer 9 on Ps 55 will be investigated below.

11. It is conspicuous that Ps 55 also displays similarities with other parts of Jeremiah, e.g. the rare word רוד which occurs in the hitpael in Jer 2,31 (Ps 55,3) and trembling of the heart (Ps 55,5) which is described in Jer 4,19. 
same applies to Ps 55 at least in its present form. ${ }^{12}$ If this is the case, the intertextual connections between 1-2 Sam, Ps 52, Ps 55, Jer 9 and Proverbs might provide insight into the ideological thinking of the editors of the Psalter: the problems their in-group faced, the solutions they proposed and the hope they fostered. Contextualisation of Ps 55 within the immediate cluster and in its relationship to 1 Samuel, Jer 9 and Proverbs provide a hermeneutic key to understand how the editors of the Psalter wanted their readers to understand the psalm.

The intertextual context of Ps 55 will subsequently be explored: its links to Ps 52 and the rest of the cluster will be summarised, its similar (like Ps 52) dependence on Jer 9 and Proverbs will be investigated in greater detail, and its applicability to the life of David will be explored. From this investigation certain conclusions will be drawn about the ideological interests of the editors of the Davidic Psalter. The first step must be, however, to introduce Ps 55 itself.

\section{Psalm 55 - An Overview}

${ }^{1}$ For the conductor, on stringed instruments. A teaching psalm of David.

I A ${ }^{2 a}$ Give ear to my prayer, $\mathrm{O} \mathrm{God},{ }^{2 \mathrm{~b}}$ and do not hide yourself from my pleading!

${ }^{3 a}$ Pay attention to me and answer me; ${ }^{3 \mathrm{~b}} \mathrm{I}$ am restless* in my complaint and I groan,

${ }^{4 a}$ because of the voice of the enemy, ${ }^{4 b}$ because of the oppression of the wicked. ${ }^{4 \mathrm{c}}$ For they rain* trouble upon me and with anger they oppose me.

B ${ }^{5 a}$ My heart trembles in my inner being; ${ }^{5 b}$ the terrors of death have fallen on me.

${ }^{6 \mathrm{a}}$ Fear and trembling come over me, ${ }^{6 \mathrm{~b}}$ and horror has overwhelmed me.

C ${ }^{7 a}$ And I said: If only I had a wing like a dove! ${ }^{7 b}$ I would fly away and stay there.

${ }^{8 a}$ Yes, I would cover a great distance to escape! ${ }^{8 b}$ I would stay in the wilderness. Selah.

${ }^{9 \mathrm{a}}$ I would hurry to find a shelter for myself ${ }^{9 \mathrm{~b}}$ from the raging wind, from the gale.

II D ${ }^{10 \mathrm{a}}$ Confuse, O Lord, split their tongue; ${ }^{10 \mathrm{~b}}$ for I have seen violence and conflict in the city.

${ }^{11 \mathrm{a}}$ Day and night they encircle it on its walls, ${ }^{11 \mathrm{~b}}$ and wickedness and trouble are within it.

12. Gosse: 2004, pp. 58-77 has argued that Jer 9 was influenced by Ps 55, but it will be argued below that the opposite is true. This is not to deny that in certain parts of Jeremiah, especially in the so-called "confessions of Jeremiah," the editors have made use of material which they found in the Psalter or which they simultaneously inserted into the Psalter. 
${ }^{12 \mathrm{a}}$ Destruction is within it; ${ }^{12 \mathrm{~b}}$ oppression and deceit do not depart* from its public square.

E ${ }^{13 a}$ Indeed, it is not an enemy who ridicules me, I could bear that; ${ }^{13 b}$ it is not an enemy who deals insolently with me, ${ }^{13 c}$ otherwise I would hide from him.

${ }^{14 a}$ But it is you, a person who is from my rank, ${ }^{14 b}$ a close friend and one in whom I confided,

${ }^{15 a}$ we who had sweet fellowship together $-{ }^{15 b}$ in the house of God we moved about in the tumult.

F ${ }^{16 a}$ May death* surprise them; ${ }^{16 b}$ may they go down to Sheol alive; ${ }^{16 c}$ for evil deeds are in their storage room, in their midst.

III G ${ }^{17 a}$ But I will call to God, ${ }^{17 b}$ and Yahweh will save me.

${ }^{18 \mathrm{a}}$ Evening and morning and at midday I complain and groan, ${ }^{18 \mathrm{~b}}$ and he hears my voice.

$\mathrm{H} \quad{ }^{19 a} \mathrm{He}$ redeems my life in safety from the battle that I wage, ${ }^{19 b}$ even though many are against me.

${ }^{20 a}$ God will listen and humiliate them, yes, he who is enthroned from the beginning, ${ }^{20 \mathrm{~b}}$ Selah, because there is no change for them ${ }^{20 \mathrm{c}}$ and they do not fear God.

${ }^{21 a} \mathrm{He}$ stretched out his hand against those who were at peace with him; ${ }^{1321 \mathrm{~b}}$ he violated his covenant.

I ${ }^{22 \mathrm{a}}$ His mouth was smooth as butter, yet war was in his heart; ${ }^{22 \mathrm{~b}}$ his words were softer than oil; ${ }^{22 \mathrm{c}}$ yet they were drawn swords.

IV J ${ }^{23 a}$ Throw your burden ${ }^{14}$ upon Yahweh, he will sustain you; ${ }^{23 b}$ he will never allow the righteous to be moved.

$\mathrm{K}{ }^{24 \mathrm{a}}$ But you, O God, will bring them down to the pit of destruction; ${ }^{24 \mathrm{~b}}$ men of blood and treachery shall not reach half of their days. ${ }^{24 \mathrm{c}}$ But as for me, I will trust in you.

\subsection{Notes on the text and translation}

Verse 3b: "I am restless." This is a hiphil imperf of רוּר, "to be restless" or "to wander about." BHS suggests אוּרוּד (a hophal imperf of "to be or become downtrodden") on account of the Vulgate humiliatus sum. This is not necessary.

Verse 4c: מוּט hi "to cause to sway" is unclear. Hossfeld and Zenger assume a meaning such as "roll/shove upon."

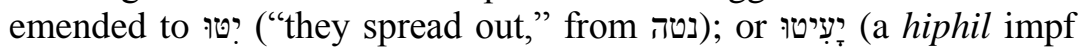

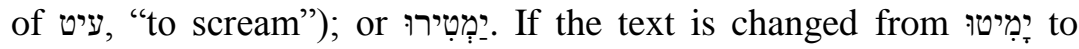
יִמְטירוּ as as most modern translations suppose, the meaning "cause to rain" can be obtained and this seems to be an acceptable possibility.

13. The expression refers to people to whom a commitment has been made or who live in peace or friendship with one: Cf. Jer 20,10 ("trusted friends"); 38,22 ("close friends"); Obadiah 7 ("the men at peace with").

14. יהב is an Aramaic loanword (cf. Köhler \& Baumgartner: 1994, s.v.

15. Hossfeld \& Zenger: 2005, p. 51. 
Kselman and Barré keep מוּט (which they translate with "maliciously rage"), and cite the repetition of מוּט in v. 23 as an instance of inclusion (Kselman \& Barré: 1998, 442).

Verse 12b: The verb is מושישיש II and the form is thus a qal impf, "to depart, withdraw from." This may be an ironic reference to Josh 1,8 (the book of law should not depart, לאיימוש, from Joshua's mouth and he must meditate on it "day and night"), cf. Ps 55,11 "day and night."

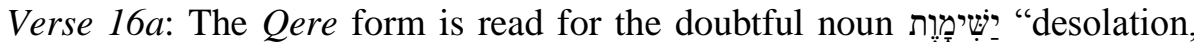

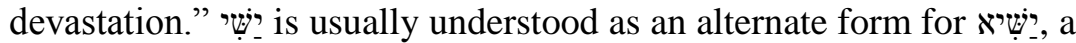
hiphil jussive from II נִָָׁ "to cheat, deceive." Thus: "May death sur-

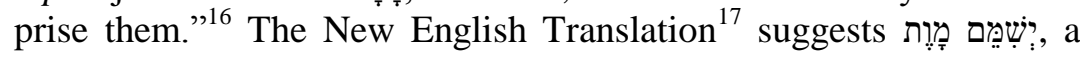

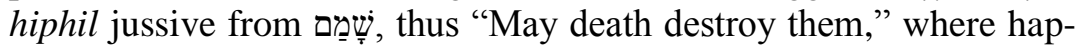
lography has reduced three mems to one. The prepositional phrase is then understood as a scribal addition to make sense of a corrupted text. This is perhaps going too far.

\subsection{The structure and contents of Ps $55^{18}$}

The first stanza (vv. 2-9) is a supplication to God to pay attention to and help the psalmist. His problem is the words and actions of people who oppose and oppress him (strophe A, vv. 2-4). By way of supporting the call for help, the suppliant describes the effect of the actions of the enemy: He experiences fear, trembling and horror (strophe B, vv. 5-6). The suppliant then describes how he would have preferred to escape from this situation of oppression to the wilderness like a dove would flee before a storm (strophe C, vv. 7-9).

Stanza II (vv. 10-16) is a supplication to God to confuse the enemy like he did in Gen 11 at the building of the tower of Babel. The violence, conflict, oppression and deceit which goes on continually in the city troubles the psalmist (strophe D, vv. 10-12). These acts culminated in the treacherous actions of a specific individual who seemed to have been a colleague and trusted friend, but who betrayed the trust of the psalmist. He is confronted and accused directly (strophe E, vv. 13-15). The psalmist subsequently prays that the enemies be given over to death, for they are evil to the core (strophe F, v. 16).

Stanza III (vv. 17-22) is an expression of faith and trust that God will listen and intervene. It is demarcated by the emphatic use of the personal pro-

16. So also Kraus: 1978 , p. 560.

17. The NET Bible, Version 1.0 Copyright @ 2004, 2005 Biblical Studies Foundation. Electronic copy consulted.

18. The major divisions proposed here concur to a large extent with those proposed by Van der Lugt: 2010, pp. 122-123. He (pp. 129-130) points out that a fair number of investigators identify a bipartite structure consisting of vv. 2-15 and 16-24; or else 2-16 and 17-24. He (p. 130) is convinced, however, that a division into three 8-line "cantos" and a concluding "half-long" canto on the basis of rhetorical as well as formal features represents the intended segmentation more faithfully. 
noun אני in verse 17, similar to the final stanza being concluded with a similar use of in verse $24 .{ }^{19}$ The psalmist's continual calling and complaints will be answered by Yahweh (strophe G, vv. 17-18). God will intervene in this battle because of the enemy's disregard for him (strophe H, vv. 19-21). The treacherous deceit of the friend who turned into an enemy is described again in strophe I (vv. 21-22).

Stanza IV (vv. 23-24) is the conclusion. It contains an admonition to fellow believers to let Yahweh take care of their troubles, since he is faithful to the righteous (strophe J, v. 23). In the final strophe, the psalmist once more addresses God directly (as in stanza I), confessing his belief that God will quickly end the life of men of blood and treachery. The psalmist, in contrast, will keep on putting his trust in God (strophe K, v. 24).

With its many resemblances to the so-called "laments" of Jeremiah, ${ }^{20}$ the impression the psalm leaves is that it was composed by someone in a similar situation as "Jeremiah." This individual was living as a righteous person in a city taken over by violence and conflict, wickedness, oppression and deceit. ${ }^{21}$ The inhabitants were rotten to the core. ${ }^{22}$ Because he was the object of attack from all sides, of angry opposition and ridicule, the suppliant would have liked to desert the city and go to live in the wilderness. Especially the treacherous intent of an intimate friend overwhelmed the psalmist. ${ }^{23}$ His only resolve was to direct his complaint to God whom he believed would judge between him and his enemies and vindicate him by giving the enemies over to a humiliating death. ${ }^{24}$ The superscript given to the psalm and its editorial incorporation into the cluster of Pss 52-55, however, rather situates it in the experience of David. It seems that the editors were not determined to avoid ambiguity between these two contexts of reference (the life of "David" and the life of "Jeremiah").

\section{Psalm 55 in the Context of the Cluster Pss 52-55}

Psalm 55 forms an integral part of the whole cluster. There are various connecting lines between Pss 52-54 individually on the one hand and Ps 55 on the other, but the connections between Pss 52 and 55 seem especially strong.

19. So also Kselman \& Barré: 1998, p. 442.

20. Cf. the "trembling" of the heart and the anguish in the intestines in Ps 55,5 and Jer 4,19; the motif of fleeing to the wilderness in Ps 55,7-9 and Jer 9,1 (although in Jer 9,1 it is Yahweh who is speaking); the corrupted state of the city (Jerusalem) in Ps 55,10-12 and in Jer 5,1-2; 6,6-8; 9,1-5 and 29,5-6; the betrayal by a close friend and the prayer for retribution in Ps 55,14-16 and 21-22 and the similar experience and prayer of Jeremiah in Jer 20,10-12. Pashhur would be the "friend" who betrayed Jeremiah, cf. Jer 20,1-6.

21. Cf. Jer 4,$14 ; 5,27 ; 6,7 ; 9,5.7 ; 20,8.18 ; 22,3$.

22. Cf. Jer 4,$14 ; 6,6 ; 9,7$.

23. Cf. in this regard Jer 11,$21 ; 12,6 ; 20,10$ (cf. Ps 55,21).

24. E.g., Jer 17,18; 20,11. 
Keywords which connect each of these psalms with Ps 55 are listed below (those which occur also in one or more of the other members of the cluster are highlighted):

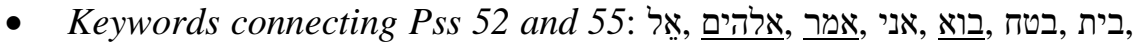

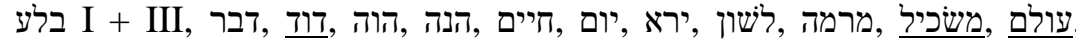
רב, רעה, ,צדיק

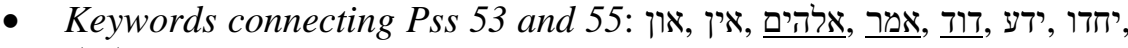

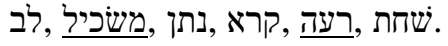

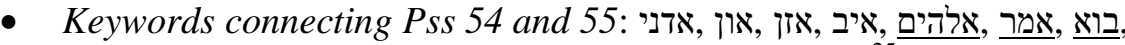

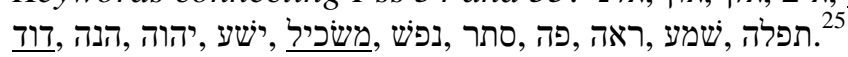

Thirty-four lexemes are shared by Pss 52 and 55, of which about 15 can be considered to be significant keywords which also do not occur in either Pss 53 or 54. It seems that the editors of the cluster made a conscious attempt to connect Pss 52 and 55. The occurrence of the homonym בלע I ("to swallow" in 52,6) ${ }^{26}$ and III ("to confuse" in 55,10), ${ }^{27}$ both used in connection with the "tongue" as metaphor for "speech," already serves as an indication of this. A number of repeated keywords also convey the same or a similar thought, for example the pronoun ' אני, "I," in 52,108 and 55,24. ${ }^{29}$ It is used at the end of both psalms in an adversative sentence to contrast the happy fate of the psalmist with the calamity which will overwhelm the enemy. ${ }^{30}$ Closely associated with the first person pronoun with its emphatic use, one also finds the verb ("to trust") in both psalms $(52,9.10 ; 55,24)$. In both psalms, it serves to distinguish the psalmist and the enemy: The rich antagonist of Ps 52 "trusted" in the abundance of his riches, while the suppliant "trusts" in the steadfast love of God (Ps 52,10). In Ps 55,24, he "trusts" in Yahweh. ${ }^{31}$

25. Hossfeld \& Zenger: 2005 , p. 56 discuss the links between the two psalms in terms of the superscriptions, the similarity in the petitions to God to listen, the distribution of divine names throughout the two psalms, the references to Yahweh's help $(54,3$ and 55,17), the confessions of trust, the descriptions of the behaviour of the enemies, the certainty of being heard, and the connection of each to the Temple. According to them, these connections "make it understandable why the two psalms were arranged in sequence."

26. As a metaphoric description of the violation of other people's rights.

27. As a metaphoric description of the punishment of offenders who violate human rights.

28. "But $I$ am like a green olive tree in the house of God."

29. "But as for me, $I$ trust in you."

30. The presence of the pronoun with waw-adversative often marks a caesura and introduces a pronouncement which serves as a "Bekenntnis der Zuversicht" or "Gewissheit der Erhöhrung." Cf. Weber: 2005, p. 127. He cites in addition to Ps 13,5 also $31,7.15 ; 52,10 ; 55,24 ; 71,14 ; 73,23$.

31. As Tanner: 2014, p. 479 notes, confident trust is a theme of Pss 54-59 and 61-63. She has not taken note of the connections between Pss 52 and 55. 
Deceitful words and speech and the wrong use of one's tongue are mentioned in both psalms. In Ps 52,6, the powerful antagonist is accused of loving "all words" (כל־ברי) "that devour" (בלע I) and he is metaphorically addressed as a "deceitful tongue" (לשון מרמה). In Ps 52,4 he is also accused of being a "tongue" (לשון) which plans destruction (לישר) "like a sharp razor." The antagonist of Ps 55 in turn has "words" (דבריו) which are softer than oil, but are dangerous like "drawn swords" $(55,22)$. The psalmist asks the Lord in Ps 55,10 to "confuse" (בלע III) and to "divide" the "tongue" (לשון) of the enemy. The word ("destruction") is used in both psalms to describe the harm caused by the antagonists. "Destruction" is what the evildoer of Ps 52,4 plans; and it is used together with ("fraud") to describe the prevailing actions of the wicked in Ps 55,12..$^{33}$ The word רעה, "evil," can also be mentioned in the same vein: The evildoer of Ps 52,3 boasts about evil, while evil is said to be in the dwelling place, in the midst of the enemies in Ps 55,16.

"Life" (חיים) is used in both psalms to describe the judgement of God which will result in the death of the enemy (cf. Ps 52,7, "uprooted" from the "land of the living"; Ps 55,16, going down to Sheol "alive"). The verb ירא ("to fear, show reverence") serves to define the difference between the righteous community and the evildoers in the two psalms (Ps 52,8, the righteous will "fear" when they perceive God's judgement; in Ps 55,20 the enemies will be humbled "because they do not change and do not fear God").

The word עולם, "forever," is also given a similar function in the two psalms (Ps 52,10 and 11: "I trust in the steadfast love of God forever and ever"; and "I will thank you forever, because you have done it"; in Ps 55,23, Yahweh will never permit the righteous to be moved). The in-group of the suppliant is described as "the righteous" in both psalms (Ps 52,8 and Ps $55,23)$.

Despite the differences between Pss 52 and 55, there are thus significant similarities. These can be summed up by stating that in both psalms a person who perceives himself to be part of the "righteous" (צדיקים) or "faithful" (חסידים) in-group $(52,8.11 ; 55,23)$ has to contend with "evil" (רעדם) opponents $(52,5 ; 55,16)$ who use their "tongue" (לשון) $(52,4 ; 55,10)$ to commit "fraud"

32. Hossfeld \& Zenger: 2005, 54 regard בלע in Ps 55,10 also as the one which has the meaning of "swallow."

33. It is possible that this lexeme was also abstracted by both psalms from Jer 9. In Jer 9,4, the last stich says, "They taught their tongue to speak deceit, they weary

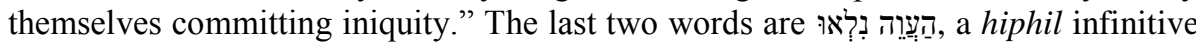
absolute of עוה, "to go astray," and a niphal perfect of לאה, "to be tired." Thus: "They

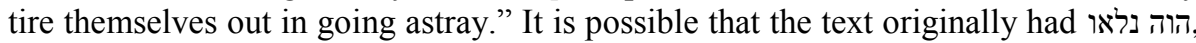
"they tire themselves with destruction." Through an error of hearing or reading, הוה was changed into העוה. Some commentators follow the LXX in separating the first

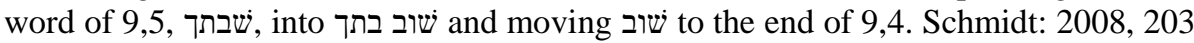
translates the last two words of 9,4 and the first part of the first word in 9,5 as "sie handeln verkehrt, sind nicht mehr imstande 'umzukehren'." 
(מרמה ,רמיה) (52,4.6; 55,10.12) and wreak "havoc" (55,12). The reaction of the righteous suppliant is to "trust" (בטה) in God in both psalms $(52,10 ; 55,24)$ because he knows that God will humiliate the opponents $(52,8-9 ; 55,20)$ and punish them by causing them to die an early death (cf. the use of חיים) (52,7; 55,16.24).

\section{THE DUAL CONNECTION OF PSS 52 AND 55 WITH JER 9}

The connections between Pss 52 and 55 grow in importance in view of their respective links with Jer $9 .^{34}$ Both psalms have a literary connection with Jer 9 , in other words, the similarities are not the result of shared motifs, but of allusion or borrowing. ${ }^{35}$ The direction of influence is contested, however. Bernard Gosse has argued that the author of Jer 9 drew inspiration from Ps $55 .^{36} \mathrm{I}$ do not think this is correct. The reason for my belief is that both psalms have links to the same motifs in Jer 9. This already favours the possibility of Jer 9 being the source text, ${ }^{37}$ but the odds grow significantly when one considers that Pss 52 and 55 also have additional literary links to separate sections of Jer $9 .{ }^{38}$ On top of that, certain pronouncements in Ps 52 become completely transparent only if they are read against the background of Jer 9 , while Jer 9 does not become more comprehensible when read in the light of Ps 52. There is also at least one phrase in Ps 55 which seems to reflect a different reading of the consonantal text of Jer $9 .{ }^{39}$ All three texts also have con-

34. Some of the similarities can in fact be attributed to the connections with Jer 9 .

35. This can be asserted in support of Fischer's finding in view of a number of cases he investigated that Jeremiah served as theological, literary, and spiritual inspiration for many psalms rather than the opposite, even though he expresses doubt about the "Motiv-Parallelen" between Jer 9,1 and Ps 55,7-8. Cf. Fischer: 2010, 476-478.

36. Gosse: 2004 , pp. 58-77. Gosse looks only at the first eight verses and has also not taken into account the connections of the whole chapter of Jer 9 with both Pss 52 and 55, or the connections between the two psalms and Ps 49. The "influence" of other psalms he identifies in Jer 9 can probably also be explained more satisfactorily as inspiration the editors of the psalter obtained from Jeremiah. Examples are the influence of Jer 9,2 on Ps 11,$2 ; 84,4.8 ; 119,86$; Jer 9,3 and 7 on Ps 28,3; and Jer 9,5 on Ps 10,7.9.

37. Jer 9,1-10 is closely related to chapters $2-6$, taking up certain motifs from it such as "truth" (both אמת אמונה), "deceit," "adultery," "to flee," "to avenge," "slandering," "falsehood," "one another," "do not know God," and "desertedness" to name a few. According to Schmidt: 2008, p. 205, "Der Text scheint hier und da bereits auf die in der ältesten Sammlung (in Kap. 1-6) bewahrte Überlieferung zurückzugreifen, sie abgewandelt aufzunehmen und gehört vermutlich zur ersten, frühesten Ergänzung."

38. Jer 9 has exerted an influence on quite a number of psalms, e.g. Ps 11,$2 ; 49,6-7$; $84,4.8 ; 119,86$. It would be almost impossible to argue that Jer 9, which is coherent to a great extent, has made use of all these different contexts.

39. Jer 9,5 begins by stating "Your dwelling is in the midst of deceit" (מרמה בתוך

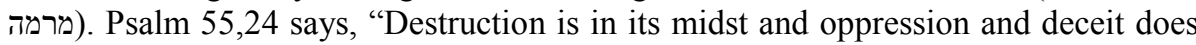


nections with Proverbs, but Ps 52 is an extremely precisely crafted wisdom composition (cf. Botha: 2013). The most logical conclusion about their relationship would therefore be to suggest that the author of Ps 52 made his composition by integrating material from Proverbs and Jeremiah, while Ps 55 in its present form seems to be the adaptation of an older poem which had been edited to reflect the language and motifs of both Jer 9 and Ps 52, also incorporating contexts from Proverbs. In view of the influence extending from Jeremiah and the connections with Ps 52, Ps 55 in its present form must have been composed somewhat later than the time of composition of Ps 52, indicated by Beyerlin as between the middle of the fifth and the middle of the fourth century B.C.E. (thus 450-350 B.C.E.) (cf. Beyerlin: 1980: 94).

\subsection{The intersection between Jer 9, Pss 52 and 55}

\subsubsection{The motif of wisdom and knowledge of Yahweh (שכל)}

The first lexeme of the significant ${ }^{40}$ ones which are shared by Jer 9 , Pss 52 and 55, is the stem שכל. All the psalms of the cluster are described in their respective headings as "a Maskil." It may be coincidence that Jer 9,23 uses the hiphil infinitive absolute of שכל ("to have insight"), ${ }^{41}$ but it probably is not, since Ps 53,3 (which is not investigated, but forms part of the cluster of "Maskils") uses the hiphil participle of this stem (משכיל) to describe the upright people whom God is looking for - someone "with insight, who seek after God." The stem itself is a fundamental part of wisdom language ${ }^{42}$ and, what is particularly interesting for the present investigation, is its use in 1 Sam to describe David's success in all kinds of undertakings. 1 Sam 18,14 says that David was "successful" (משכיל) in all his ways since Yahweh was with him. ${ }^{43}$

not cease from its market-places" (הוות בקרבה ולא-ימיש מרחבה תך ומרמה). The cue for the "market-places" is found elsewhere in Jer 9 (in Jer 9,20) while the idea of the "dwelling" is represented in Ps 55,16 with "Evil things are in their store-rooms (= dwellings), in their midst" (רעות במגורם בקרבם).

40. Only those words which seem to form significant connections are listed here.

41. "... but let him who boasts boast in this, that he understands and knows me, that I am Yahweh who practices steadfast love, justice, and righteousness in the earth."

42. Almost 25\% of all occurrences are in Proverbs. Cf. its use in Prov 1,3 as part of the semantic field מזמה and ערמה, מישרים ,משפט, צדק ,חכמה ,דעת (in the context of Prov $1,1-4)$.

43. The fact that these psalms are described as "Maskils" therefore establishes a connection with the history of David. Cf. its use to describe David as successful also in 1 Sam 18,5.15 and 30. It was because of David's spectacular "success" (which was the result of Yahweh being with him, 1 Sam 18,14) that Saul became afraid of him. Success is also promised to Joshua in Josh 1,7-8 ("so that you can have success, תשיל, wherever you go"; "then you will make your way prosperous (תצליח), and then you

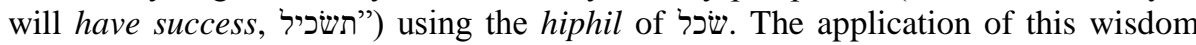
pronouncement from Josh 1,8 in Ps 1,3 is well-known. 


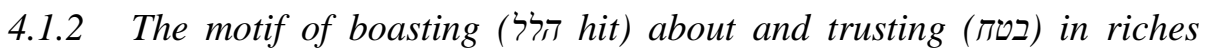

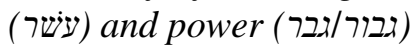

The verb "to trust") is used in the Psalter to qualify the righteous who put their trust in Yahweh's ability to save them even when the odds are against them. One alternative for some people in the post-exilic era was to put trust in their wealth (cf. Ps 49,6, 52,9 and 10). The verb occurs also in Jer 9,3 , but there it is used to warn the people of Judah not to trust a friend or brother. It therefore does not seem to be directly related to the use of "trust" in Pss 52 and 55, but the context of Jer 9 is indeed relevant for understanding the verb בטח in Pss 52 and 55. This necessitates that the intersection between Jer 9 and Ps 52 be discussed first, before moving on to the connections with Ps 55.

The "trust" of the evil opponent and his "boasting" of "evil" in Ps 52, in contrast to the "trust" of the righteous suppliant in Yahweh (in both Pss 52 and 55) can only be fully understood within the context of Jer 9. Jer 9,22-23 says:

Thus says Yahweh: "Let not the wise man boast (יתהלרל) in his wisdom, let not the mighty man (הגבור) boast (ניתלור) in his might (בגבורתו), let not the rich man (עשיר) boast (יתהלל) in his riches (בעהרו)), but let him who boasts (המתהלל) boast (השלל) in this, that he understands (השכל) and knows me, that I am Yahweh who practices steadfast love (חס), justice, and righteousness in the earth. For in these things I delight, says Yahweh" (Jer 9,22-23). ${ }^{44}$

Psalm 49,6-7 uses the description of those who "boast" in their "riches" in a parallelism in which the parallel part uses "trust" (בטח) as a synonym for "boast" (יתהלל)); and "power, strength, wealth" (חיל) as a synonym for "riches" (עשר):

Why should I fear in times of trouble, when the iniquity (עון) of those who cheat me (עקבי) surrounds me, those who trust (הבטחים) in their wealth (עילם) (עילם) and boast (עיתללו) of the abundance (ברב) of their riches (ערטם)? (Ps 49,6-7).

There cannot be any doubt that the author of Ps 49 is alluding to the whole chapter of Jer 9, since Jer 9,3 warns the people of Judah that no friend or brother should be trusted (אל־תבטחו), since every brother is a deceiver ( עקוב (יעקב and every friend is a slanderer (רכיל יהלך). The author of Ps 49 has thus

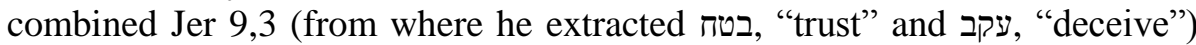

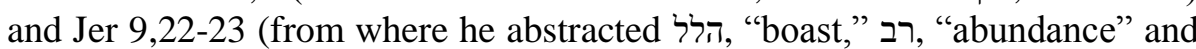
עשר, "riches"). The same problem that is addressed in Ps 49 is also tackled in Ps 52, possibly by the same author. The author there goes one step further,

44. This prophetic saying is based on the wisdom pronouncement about guarding against arrogance (e.g. Prov 27,1, "Do not boast about tomorrow, for you do not know what a day may bring"). According to Schmidt: 2008, p. 212, "Der Prophet kann die Mahnung, sich nicht selbst für weise zu halten, aufnehmen und zur Anklage zuspitzen." The warning against "trusting" in one's "riches" (cf. Prov 11,28) seems to have played a role also. 
however, because the rich opponent is accused in Ps 52,3 of "boasting (הלל) hit) in evil (רעה)" while he is (ironically) addressed as "O mighty man (הגבור)," thus someone who considers himself to be powerful:

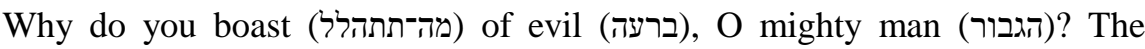
steadfast love (דח) of God endures all day long (Ps 52,3).

A little further on in Ps 52 it is said that the righteous shall see how this arrogant, evil person is uprooted from the land of the living and that they (the righteous) will fear (God) and laugh at this person, saying,

"See the man (הגבר) who would not make God his refuge (לאר ישים אלהים מעוזו), but trusted in the abundance of his riches (נויבטח ברב עשרו) and was strong (יערים) in his destruction (בהותו)",45 (Ps 52,9).

The author of Ps 52 has therefore extracted the words "trust" (בטח), "boast" (הלל hit), and "the abundance" (עבר) of "riches" (ער ) from Jer 9 (exactly similar to what happens in Ps 49,6-7), but he has also borrowed the idea of the "mighty man" (הגבור) from Jer 9,22 and applied this to the "rich man" from Jer 9,22 which he combined with the motif of "evil" (רערה) and the motif of "growing strong" (גבר) which he found in Jer 9,2. "46 The cryptic, antithetic remark in Ps 52,3 that "the steadfast love (חסר) of God endures all day long" only becomes understandable in view of Jer 9,23. In castigating the things in which the people of Judah "boast" in Jer 9,22, Yahweh says that the only thing in which people should boast, is that they are wise (השכל) and that they know Yahweh, the one who "does (עשה) steadfast love (חסד)." It is also this verse which helps us to understand why the author of Ps 52 says in verse 11, "I will thank you forever, for you have done it (כי עשית)." He thanks Yahweh for "doing, practicing," steadfast love.

The links between Jer 9, Ps 49, and Ps 52 thus indicate that Jer 9 was used as a source to argue that the opponents of the author or authors of Pss 49 and 52 were rich, arrogant and powerful people who attained their position through deceit and who were not interested in having wisdom about Yahweh or to know him. The treacherous way in which they used their tongue is also singled out in Pss 52 and 55, with a direct link to Jer 9.

\subsubsection{The motif of using the tongue (לשון) as a weapon: Deceit (מרמה/רמיה), lying (שקר), and plotting against the righteous}

In Jer 9,1, the people of Yahweh are accused by him of being adulterers and a company of "treacherous" men. They are described as "bending" (ידרכו) their

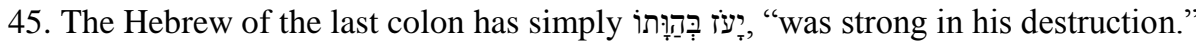
This is an objective genitive, referring to the destruction effected by the evildoer with his tongue (cf. Ps 52,4, Ps 5,10).

46. "Not according to truth have they grown strong in the land, for they proceed from evil to evil, and they do not know me, declares Yahweh." 
tongue (לשונם) like a bow, arming it with deception (שקר)" (Jer 9,2). ${ }^{47}$ A little further on, the tongue itself is compared to a "deadly" or "sharpened" arrow:

${ }^{2}$ They bend their tongue (לשונם) as their bow with deception (שקר); not according to truth have they grown strong in the land; for they proceed from evil to evil (מרעה אל־רעה), and they do not know me, declares Yahweh. ${ }^{3}$ Let everyone be on his guard against his neighbour and put no trust in any brother, for every brother is a deceiver, and every neighbour goes about as a slanderer. ${ }^{4}$ Everyone deceives his neighbour, and no one speaks (ידברו) the truth (אמת); they have taught their tongue (לשונם) to speak lies (דבר־שקר); they weary themselves committing iniquity. ${ }^{5}$ Your dwelling (שמם) (במר) (במרך) is in the midst of deceit (בתוך מרמה), and in deceit (במרמה) they refuse to know me, declares Yahweh. ${ }^{6}$ Therefore, thus says Yahweh Sebaot: "Behold, I will refine them and test them, for what else can I do, because of my people? ${ }^{7}$ Their tongue

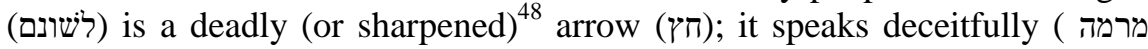
דבר ); with his mouth (בפיו) each speaks peace (שלום) to his neighbour, but in his heart (בקרבו) he plans an ambush for him (ישים ארבום) (Jer 9,2-7).

This whole section has found appropriation in both Pss 52 and 55. In both psalms, deceiving speech is represented as a dangerous weapon: The "tongue" is compared to a sharp razor in Ps 52 and "words" are described as drawn swords or daggers in Ps 55. In both psalms there is also the idea of planning or plotting against fellow Israelites. Lying (שקר) is also taken up in Ps 52 from Jer 9:

${ }^{4}$ Your tongue (לשונך) plots (תחשב) destruction (הוות), like a sharpened (מלטשש)

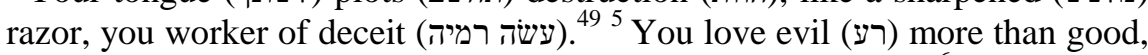

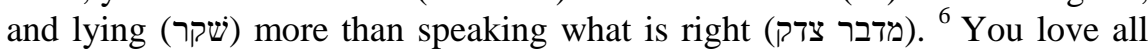
words that devour, O deceitful tongue (לשון מרמה) (Ps 52,4-6).

Instead of the "tongue" being a "sharpened (שחוט) arrow" (Jer 9,7), it is described in Ps 52,4 as a "sharpened (מלטש) razor" (Ps 52,4). "Lies" (שקר) and "deception" (מרמה), the practicing of "evil" (רערות) (רער) (מרע) and the absence of "speaking" (צבר) the "truth" (צמת) or alternatively "what is right" (צדק) are mentioned in both contexts. The "ambush" (ארב) which the antagonist of Jer

47. The ESV ignores the Masoretic accent (Zaqeph Qaton) at שק and erroneously reads it as part of the next colon. Cf. the better rendering of the NET in this regard.

48. The consonantal text has שin but it has been vocalized by the Masoretes as a passive participle, שִׁ. Köhler \& Baumgartner: 1994, s.v. שח II interprets this as "perhaps a whetted (sharpened) arrow."

49. can serve as an adjective ("slack" or alternatively "treacherous"), an adverb ("slackly"), or a substantive ("fraud, deception"). Cf. Köhler \& Baumgartner: 1994, s.v. רמיה. It functions in Ps 52,4 as a substantive, but the association with a bow as in the adjective "slack bow" was possibly not altogether absent. 
9 "plan" (שים ארב בקרב) is described as "plotting" (חשבב) "destruction" (הוות) in Ps $52,4 .^{50}$

In Ps 55, it is the "mouth" and the "words" of the antagonist which are described as dangerous, and in particular his words are compared to "drawn" swords or daggers.

${ }^{21} \mathrm{He}$ stretched out his hand against those who were at peace with him (בשלמיו), he violated his covenant. ${ }^{22}$ The butter of his mouth (פיו) were smooth, but his heart (לבו) was war; softer than oil were his words, but they were drawn swords (פתיחות) (Ps 55,21-22).

The theme of plotting against a neighbour is actually extrapolated in Ps 55. Where Jer 9 speaks of "speaking friendly" (דבר שלום) with the "mouth" (פה) with a neighbour while planning an ambush in one's heart (לבר), Ps 55 refers to "stretching out the hand" against those who are "at peace" (שלום) with one, having "butter" in one's "mouth" (פה) while there is war in the "heart" (לב). The idea of hiding one's true intentions deep inside (בקרבו) in Jer 9,7 is repeated in Ps 55,16 where the author says "evil (בעות) is in their dwelling place (במגורם), ${ }^{51}$ in their midst (בקרבם)." The word "midst" (קרב) plays an important role in Ps 55, since it occurs also in Ps 55,11-12 where it describes the situation of iniquity, trouble, ruin, oppression, and fraud persisting in the city:

${ }^{11}$ Day and night they go around it on its walls, and iniquity and trouble are within it (בקרבה); ${ }^{12}$ ruin is in its midst (בקרבה); oppression and fraud (תרה) תך (ומרמה do not depart from its marketplace (מרחבהת) (Ps 55,11-12).

The marketplaces of Jerusalem are mentioned in Jer 9,20. This is where the people of Judah lament that "death has come up into our windows; it has entered our palaces, cutting off the children from the street and the young men from the squares (מרחבות)." The use of the motif is therefore not the same, although the reference to the marketplace may have been inspired by Jer 9,20. Jeremiah 9,5 does, however, display a remarkable similarity with Ps 55,12 :

${ }^{5}$ Your dwelling is in the midst of deceit (שבתך בתוך מרמה); in deceit they refuse to know me, declares Yahweh (Jer 9,5).

It is possible that the author or editor of Ps 55 understood or read שבתך

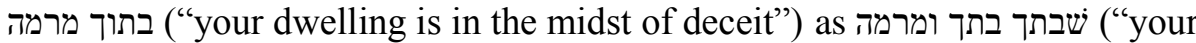
dwelling is in oppression and fraud") and consequently wrote in Ps 55,12 בוות ("מרבר ("מרמה "ruin is in its midst and oppression and fraud

50. Through the novel combination of all these motifs, it would seem that the author of Ps 64 also had Jer 9 at hand, but was confronting the same situation that concerned the author or authors of Pss 52 and 55.

51. A מָגזוֹ is a grain pit or storage room, metaphoric language for one's "heart" or "mind." Cf. Köhler \& Baumgartner: 1994, s.v. רמָּר 
do not depart from its marketplace"), taking the cue of "marketplace" from Jer 9,20 (in the sense of "the centre of the city," thus parallel to "midst"). ${ }^{52}$

\subsubsection{The motif of wanting to escape from the city}

One of the recurring motifs in the book of Jeremiah is the desire expressed by Yahweh to abandon his people. In Jer 9,1 it is expressed in the form of a wish to leave them and settle in the wilderness because of their adultery and treachery: $:^{53}$

${ }^{1}$ Oh that I had (מיייתנני) in the wilderness (במדבר) a lodging place (מלון) of travellers, that I might abandon my people and go away from them! For they are all adulterers, a company of treacherous men (Jer 9,1).

In Ps 55,7, the poet suffers from the oppression of the wicked which causes fear and trembling in him. This inspires in him the wish to flee:

${ }^{7}$ And I said, "Oh, that I had (מיייתן־לי) wings like a dove! I would fly away and settle there; ${ }^{8}$ yes, I would escape to a far place (ארחיק נדד), I would lodge in the wilderness (אלין במדבר) (Ps 55,7-8).

Instead of a lodging place, the poet of Ps 55 is looking for a place of refuge (מפלט) which would be more fitting for the simile of a dove fleeing before the storm (cf. Ps 55,9). The suppliant of Ps 55 is also not abandoning his people, but fleeing from the oppression of the wicked. ${ }^{54}$ The similarity of lexemes becomes more conspicuous, however, when one considers that the stem עוף (as a noun, "birds," and not as a verb) and (in the same function, "to flee") are also mentioned in Jer 9. In Jer 9,9, Yahweh declares his intention to take up weeping and wailing for the mountains and the pastures of the wilderness, since "the birds (עוף) of the air and the wild animals have fled (נדוד) and are gone." air" is a motif which occurs also in Jer 4,25, it is reasonable to consider the book of Jeremiah and especially Jer 9, with the wish to flee and the comparison with a bird, to be the source of the motif in Ps 55.

52. Since "David" is seen as the author of the psalm, Ps 55 could not be understood to refer to Jerusalem if Saul was the antagonist. If the antagonist was Ahithophel, it could be Jerusalem. See below.

53. The wish in Jer 9,1 seems to be a response to the prophetic questions in 8,19 and 22 about Yahweh's absence from Jerusalem. Cf. Schmidt: 2008, p. 204.

54. As Hossfeld \& Zenger: 2005, p. 54 explain, the focus of Ps 55 is the totality of corruption which effects the whole city from perimeter to centre (walls to market, going around, dwelling in the midst) and covering the totality of time (day and night). "The city has been perverted from a place of protection to a space of threatening danger; the sheltering walls have become siege barricades."

55. This similarity was also noted by Kselman \& Barré: 1998, p. 448. 


\section{Wisdom Influence in Ps 55}

According to Gosse $(2008,77)$, Ps 55,22, "The butter-like [words] of his

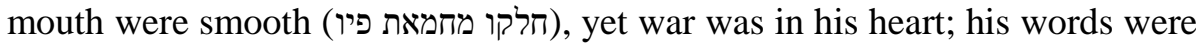
softer than oil (רכו דבריו משמן); yet they were drawn swords (פתחתות)" displays influence from Prov 12,18 ("There is one whose idle talk are like stabs of a sword (חרב), but the tongue of the wise brings healing"). There is, however, another context in Proverbs, namely Prov 5,3-4, which seems to provide a closer parallel:

${ }^{3}$ For the lips of a forbidden woman drip honey, and her palate is smoother than oil (וחלק משמן), ${ }^{4}$ but in the end she is bitter as wormwood, sharp as a two-edged sword (חדה כחרב פיות) (Prov 5,3-4).

In this comparison, that which seems to be very sweet, turns out to be extremely bitter and that which seems to be very smooth, turns out to be extremely sharp. "To be smooth" (חלק qal, Ps 55,22) or "to make smooth" (חלק hiphil) serves in the Hebrew Bible to describe the speech of someone who flatters or deceives and can be used with "mouth," "tongue," "lips," "words," or "palate." 56 The comparison between a deceptive tongue or words and a sharp instrument is found in many places in the Psalms and Proverbs. ${ }^{57}$

Psalm 55,23 ("Cast your burden on Yahweh, and he will sustain you; he will never permit the righteous to be moved") is interpreted by many as a citation of the butter-like or soft words of the treacherous friend in Ps 55,22, ${ }^{58}$ but one would have expected a clear introduction to such a misappropriated pronouncement, such as "saying" or "namely." As the verse is written, it would more naturally have been interpreted as the encouraging words of "David," the one who is teaching from his own experience. ${ }^{59}$ These are words

56. Cf. also the use of the adjective חָּ in this regard. Kselman \& Barré: 1998, 455 point out the parallel in Prov 26,28 where פה הלק is parallel to לשון שלקר.

57. Pss 12,$4 ; 52,4 ; 55,22 ; 57,5 ; 59,8 ; 120,2-4$; Prov 25,$18 ; 30,14$. The parallel between Jer 9 and Pss 52 and 55 has already been pointed out.

58. Seybold: 1996, p. 224 describes the saying as a "zitierte weisheitliche Sentenz" used by the erstwhile friend in a way which the psalmist would have experienced as hypocrisy and betrayal ("Heuchelei und Verrat"). Hossfeld \& Zenger: 2005, p. 52 similarly think it is an "ironic quotation" of the discourse of the offenders. They cite Pss 2,2-3 and 22,8-9 as similar instances, but those two quotations cannot be misunderstood as words of encouragement like this verse, so they are not similar.

59. The similar use of "forever" in Ps 52,10-11 and "never" in Ps 55,23 also serves as an argument that the latter verse was meant as inspiration for the "righteous." The righteous are given a similar promise of triumph in connection with the demise of the evildoers in Ps 52,8-9; cf. Ps 55,24. Ps 55,23-24 are demarcated by Van der Lugt: 2010 , p. 131 as a "coda," a relatively independent concluding unit "in which the main themes of the preceding sections recur briefly." Van der Lugt says, "It is a reflection on the supplicant's experience, in which his confidence in salvation is cast in a general rule with regard to the righteous: God will sustain them (v. 23)." Brueggemann \& Bellinger: 2014, 251 similarly interpret this verse as the speaker opting out of intense transactions with God to instruct others. 
of wisdom, since ("sway, totter, stagger" or "be made to stagger") are used together with צ' צ' in only five verses in the HB, the other four being from wisdom contexts. ${ }^{60}$ The verse seems rather to be a citation of Prov 10,30 , "The righteous will never be moved, but the wicked will not dwell in the land." Exactly the same aphorism is underscored in Ps $52,{ }^{61}$ so that the parallel between Pss 52 and 55 argues against the possibility that these are the words of a "wicked" person. The first part of the verse is also perfectly at home in wisdom contexts such as Prov $16,3,{ }^{62}$ Ps $37,5^{63}$ (cf. also Ps 37,24) and Ps $112,6 .{ }^{64}$ Van der Lugt correctly states that the "quintessential thought" of Ps 55 is to be found in the first strophes of each "canto," in other words in verses 2-4, 10-12, 17-18, and 23, and especially in verse 23: Cast your burden on Yahweh for he protects the righteous. ${ }^{65}$

\section{THE CONNECTIONS OF PSALM 55 WITH THE LIFE OF DAVID}

The biographical note which links Ps 52 with the life of David is relevant for Ps 53 as well. ${ }^{66}$ Similarly, the biographical note which links Ps 54 with the life of David seems applicable to Ps 55 as well. ${ }^{67}$ So, for example, is the reader told in Ps 54,2 that the context of the psalm is the time when the Ziphites came to Saul and betrayed David with a rhetorical question: "Is David not hiding (סתר hitp) among us?" In Ps 55,13, the suppliant laments the fact that the enemy is a personal friend and not someone from whom one could hide (סתר nif). Although they are not described as "friends," Saul and David had an intimate relationship for some time and Saul even "loved him greatly" (ויאהבהו מאד) since David "found favour" in his eyes (1 Sam 16,2122).

The wish to "wander far away" and to lodge in the "wilderness" (Ps 55,8) is one that became reality in the life of David. Psalm 54,2 actually refers to the time when David was in the wilderness of Ziph $(1$ Sam 23,14$)$. It was after Jonathan visited David there in the wilderness of Ziph and the two of

60. Ps 112,6, a wisdom psalm; Prov 10,30; 12,3; 25,26.

61. Ps 52,7 warns the "doer of deceit" that God will uproot him from the land of the living, while the author compares himself in v. 10 to a green olive tree in the house of God, thus firmly established.

62. "Commit your work to Yahweh, and your plans will be established."

63. "Commit your way to Yahweh; trust in him, and he will act."

64 "For the righteous will never be moved; he will be remembered forever."

65. Van der Lugt: 2010, p. 133.

66. Psalm 53,6 (in comparison to the version in Ps 14,6) was edited by the redactors to reflect connections to the life of David. These include the fact that Saul was "rejected" by Yahweh (מאס), that he "encamped" against David (חנה), and that his "bones" (עצמות) were first scattered and later reburied by David. Cf. Botha: 2013, ppp. 598-601.

67. As Weber: 2014, p. 287 n. 9 says, the metatextual statements in the headings are partially ambiguous, so that more than one incident from the life of David could have been intended as references. 
them had made another covenant, that the Ziphites treacherously informed Saul of David's whereabouts (1 Sam 23,15-19). ${ }^{68}$ They said nothing to David, but promised the king to "deliver" David into the "king's hand" (1 Sam 23,20 ). David and his men were saved on that occasion by a messenger who called Saul away from his pursuit, and afterwards that place was called "Sela Hammahlekoth" (סלע המחלקות). This name, being etymologically related to חלק I ("to be smooth"), ${ }^{69}$ possibly provides another connection to Ps 55,22 (although it is also often related to חלק II, "to divide").

The author of Ps 55, in verse 9, speaks of "hurrying" to a place of refuge (אחישה מפלט לי). When Jonathan gives a coded message to David that he should flee, he tells his servant "Hurry! Be quick (חושה)! Do not stay!" (1 Sam 20,38). Much later, when Yahweh had saved David from this threat and from all violence, he confesses: "Yahweh is my rock and my fortress and my deliverer (מפלטי-לי), my God, my rock in whom I take refuge, my shield, and the horn of my salvation, my stronghold and my refuge, my saviour, you save me from violence (חמס)" (חמס) (ריב) (2 Sam 22,2-3). Violence) (cf. 2 Sam 22,44) are the things from which Yahweh had saved David, and precisely those things form part of the complaint in Ps 55,10. Within the context of the heading of Ps 54, namely the betrayal by the Ziphites, it is noteworthy that Saul on the second occasion gathered a huge army to pursue David: He took three thousand carefully selected men (1 Sam 26,2). It is appropriate for "David" to confess in Ps 55,19 that Yahweh redeemed his life in safety, even though they were against him "with many." When David has the opportunity to kill Saul, he refuses, leaving judgement to Yahweh: "As sure as Yahweh lives, he will smite him, or his day will come and he will die, or will go down (ירד) in battle and perish" (1 Sam 26,10). In Ps 55,24, "David" confesses that God will "bring down (תורדם) his enemy to the pit of destruction."

Psalm 55 could be applicable to the history of David's flight from Saul in many respects. Early on in the conflict between Saul and David, Jonathan asked Saul not to "sin against innocent blood" by killing David. Saul listened to him and swore that he would not be killed, but a short while later he tried again in all earnest to kill him or have him killed (1 Sam 19,4-10). In doing so, he violated his oath to Jonathan, although no "covenant" is mentioned between Saul and David (Ps 55,21). ${ }^{70}$ It was in effect also Saul who had "stretched out his hand against" those who lived in peace with him, since he gave the order that all the priests of Nob be killed. When his bodyguard refused to carry out the order (they would not "stretch out" their hands, שלח $\left.7^{\prime}\right)^{71}$ against the priests, he ordered Doeg to do so (cf. Ps 55,21). He was therefore a man of "blood and treachery" (Ps 55,24, cf. 1 Sam 22,19), and

68. For a very good analysis of the connections between Ps 54 and 1 Sam 23-25, see Johnson: 2009, pp. 49-59.

69. Cf. Köhler \& Baumgarter: 1994, s.v. מחלקת.

70. David and Jonathan twice made a covenant with one another: 1 Sam 18,3; 23,18.

71. 1 Sam 22,17. 
was brought down into Sheol before his time (Ps 55,24). David, in contrast to this, on two occasions when he had the chance to do so, refused to "stretch out" his "hand" against Saul. ${ }^{72} \mathrm{He}$ respected Saul because he was the anointed of Yahweh. In this regard, David and Saul were people from the same "rank" (ערך, Ps 55,14).

It is interesting that Ps 55 also has echoes of the other major time of distress in the life of David, when he was fleeing ${ }^{73}$ (again to the "wilderness") from Absalom. David's best advisor, Ahithophel, forsook him and joined Absalom in his rebellion (2 Sam 15,12). ${ }^{75}$ The conspiracy grew strong and many (רב) people sided with Absalom. Psalm 55,15 which speaks of "sweet fellowship (נמתיק סוד)" with the friend who eventually betrayed "David," could apply to Ahithophel. ${ }^{76}$ Psalm 55,19, which speaks of "many who are against me" (כי־ברבים היו עמדי) could then also reflect the growth in the conspiracy.

\section{THE IDEOLOGICAL DATA PROVIDED BY PS 55}

By "ideological data" I refer to the beliefs, perspectives, assumptions and values reflected in Ps 55 and the different contexts in which it is involved that define and explain the interests and needs of the editors of this cluster of psalms. ${ }^{77}$ The repeated motifs in Pss $52-55$ are: ${ }^{78}$ (1) The arrogance and insolence of powerful and rich evildoers $;^{79}(2)$ the manifestation of this arrogance through the violation of the rights of innocent people, especially through the use of language; ${ }^{80}$ (3) the trust of the faithful that God will intervene; ${ }^{81}$ and

72. 1 Sam 24,$7 ; 26,9.11$.

73. Described with the verb ברח "run away, flee."

74. Described with the noun מדבר in 2 Sam 15,23.28; 17,16 (also with לין), and 29.

75. According to the Targum, Ahithophel is the person who is addressed in Ps 55,14. Cf. Bernstein: 2005, p. 493. In the Targum on Ps 55,16 ("let death come over them,"), Ahithophel and Doeg are named together.

76. Tate: 1990, p. 55 objects to the identification of Ahithophel as the one referred to by stating that David only came to know about the betrayal by Ahithophel after he left Jerusalem, while the psalm supposes that the speaker is still in the city. The title, however, merely suggests a setting for its interpretation and this and similar detail which do not fit into the setting cannot serve as a refutation of a possible background for interpretation.

77. Cf. the definition of ideology in Elliott: 1993, p. 130.

78. A similar overview is provided in Botha: 2013, pp. 595-595.

79. Cf. the "boasting" of the powerful evildoer in 52,1 who does not make God his refuge, but trusts in his riches instead of in God in 52,9; the insolence of the evildoers who (casually) eat up God's people as if they are eating bread and "do not call upon God" in 53,5; the failure of the "ruthless men" to "set God before themselves" in 54,5 ; and the enemies who "do not change and do not fear God" in 55,20.

80. Cf. the references to the "tongue" and "deceit," the preference of lying more than speaking what is right, and the "words that devour" of the "deceitful tongue" in 52,46 ; then the fool "saying" in his heart that there is no God, and the consequent corrupt, 
(4) the expectation of judgement on the evildoers. ${ }^{82}$ If the connections with Jer 9 and with Proverbs are taken into consideration, it is especially the treachery of close associates who pretended to be friendly but harboured murderous intentions which comes to the fore. Jeremiah 9 was used by the author of Ps 52 and (possibly) the editor of Ps 55 as an authoritative source to argue that the enemies were evil, rich, arrogant and powerful people who attained their intimidating position through deceit and who were not interested in having wisdom about Yahweh or knowledge of him. Similar to what applies to the "psalms of the poor" ${ }^{\prime \prime 3}$ or the "Confessions of Jeremiah" (cf. Pohlmann: 1989, 32-40) the contentious issues were about true righteousness and Yahweh's application of the principle that the wicked will be punished and the righteous rewarded. Although these people are themselves addressed, the purpose of Pss 52 and 55 was not to argue with the opponents, but to confirm certain values for members of the in-group. ${ }^{84}$

In Ps 55, the social situation of the group of editors who placed it here and possibly modified an already existing psalm, seems to have been one of oppression (עקה) by wicked (רשע) fellow Israelites $(55,4)$ ). Those people op-

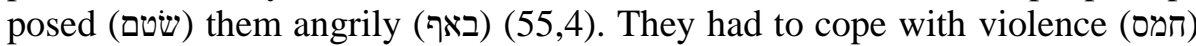
and conflict (ריב) (55,10); wickedness (5ון); (עמל); destruction (תוות); and oppression and deceit (תך ומרמה) (5רון) (55,11-12). The in-group had

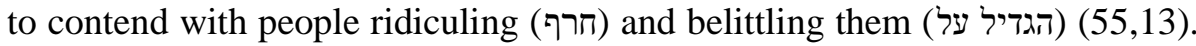
These people were evil to the core (evil deeds were "in their midst," 55,16) and they had no reverence for God $(55,20)$. Worst of all, they took advantage of the trust they enjoyed from the in-group $(55,21)$ and proved to be treacherous murderers (אנשי דמים ומרמה) (55,24).

Among the values which Ps 55 promotes is the desire to flee from these people (also expressed by Yahweh in Jer 9,1 and rephrased in Ps 55,7-9). In

abominable activities of the evildoers who "eat" up the people of God in 53,2 and 5; subsequently the oppression of the wicked who use their tongues for violence and strife, ruin and oppression in 55,4.10-12, and, finally, the speech of the opponent being smooth as butter, while he was hiding war in his heart, and his words being softer than oil, yet being drawn swords in reality, in Ps 55,22.

81. Cf. 52,10; 54,8, and 55,23 and 24 .

82. Cf. 52,7; 53,6; 54,7 and 9, and 55,16.20 and 24.

83. Gerstenberger: 2005 , p. 233 , cites from Ps $10,2-4$ and refers to the rest of the psalm to describe how the economically powerful would use their superiority for unscrupulous exploitation of those who are weaker. He also refers to Pss 37; 49; and 73, psalms which display conspicuous similarities especially to Ps 52. Gerstenberger explains how the amazing precision and severity of tax authorities since the imperial reform of Darius resulted in the impoverishment of large segments of the populations while it yielded also gains for the collaborating elite stratum of the native population. 84. As Pohlmann: 1989, p. 34 states about the "Confessions of Jeremiah," "Sie dienen in erster Linie nicht einer Art Propaganda, die sich an oder gegen die Gegenpartei richtet, sondern der Aufrichtung der Angefochtenen in den eigenen Reihen." 
the case of the psalmist, oppression and the resulting fear of death $(55,4-6)$ play an important role, while in the case of Yahweh in Jer 9 the desire to flee was motivated primarily by repulsion (Jer 9,1$)$. A second value portrayed by the psalm is the desire (expressed as a certainty) that the opponents will be judged. This would entail a confusion of their speech as in Gen 9 at the tower of Babel $(55,10$, cf. Gen 11,7), but also death in a spectacular way such as the fate which struck Korah, Dathan and Abiram so that their death would serve as proof that they had "spurned" Yahweh $(55,16$, cf. Num 16,30.33) and were consequently judged by God $(55,24)$.

A third value propagated by the psalm is the trust that God will vindicate the in-group (verification of the deed-consequence-teaching). God "listens" to the complaint and the groaning of the members of the in-group $(55,18)$ and redeems their lives in safety even though many people may be lined up for battle against them $(55,19-20)$. The psalmist (and thus the group of editors) can consequently encourage the righteous to "throw" their "burden" on Yahweh, since he is known from the experience of earlier generations of belie $\mathrm{v}$ ers such as David and Jeremiah and also from the book of Proverbs to protect the righteous, who trust in him, from being moved $(55,23)$. As Weber has pointed out, the intersection between the books of Samuel and Psalms in the form of Ps 18 (= 2 Sam 22), focuses the Davidic psalms not only on the distress caused by enemies, but on the final salvation by Yahweh and the praise owed to him (Weber: 2014, 293-294).

\section{CONCLUSION}

In its present form and within its present context, Ps 55 proclaims the message that the ruling class of wicked people in late post-exilic Judah will be exposed and deposed. King David, who had experienced similar situations of oppression and persecution, trusted in Yahweh and was rewarded with protection and eventual triumph. He had to flee before Saul and also before Absalom, who had the help of Ahithophel, and all three of these persons earlier had an intimate relationship with him. Because he acted righteously and trusted in Yahweh, he was saved and all three of these opponents died prematurely. The prophet Jeremiah had experienced similar persecution and still condemned those who trusted in their riches instead of a wise relationship with Yahweh. This was a time to be prudent in the knowledge of Yahweh and to take advice from these dedicated predecessors.

\section{Bibliography}

Bernstein, M.J. 2005. "A Jewish reading of the Psalms: Some observations on the method of the Aramaic Targum." Pages 476-504 in P.W. Flint and P.D. Miller (eds.), The Book of Psalms: Composition and Reception (Leiden: Brill). 
Beyerlin, W. 1980. Der 52. Psalm: Studien zu seiner Einordnung. Beiträge zur Wissenschaft vom Alten und Neuen Testament (Stuttgart: Kohlhammer).

Botha, P.J. 2013. "'I am like a green olive tree': The Wisdom context of Psalm 52," HTS Teologiese Studies / Theological Studies 69(1), Art. \#1962, 8 pages. http://dx.doi.org/10.4102/hts.v69i1.1962.

_ 2013. "Psalm 53 in Canonical Perspective," Old Testament Essays 26/3, 583-606.

Brueggemann, W. and Bellinger, W.H. Jr. 2014. Psalms. New Cambridge Bible Commentary (Cambridge: Cambridge University Press).

DeClaissé-Walford, N., Jacobson, R.A. and Tanner, B.L. 2014. The Book of Psalms. The New International Commentary on the Old Testament (Grand Rapids, Michigan / Cambridge, U.K.: William B. Eerdmans).

Elliott, J.H. 1993. "What is Social-Scientific Criticism?" (Minneapolis: Fortress).

Fischer, G. 2010. “Jeremia und die Psalmen.” Pages 469-478 in Zenger (ed.), The Composition of the Book of Psalms, Bibliotheca Ephemeridum Theologicarum Lovaniensium 238 (Leuven: Peeters).

Flint, P.W. and Miller, P.D. (eds.). 2005. The Book of Psalms: Composition and Reception. Supplements to Vetus Testamentum (Leiden / Boston: Brill).

Gerstenberger, E.S. 2011. Israel in the Persian Period: The Fifth and Fourth Centuries B.C.E. A translation of Israel in der Perserzeit: 5. Und 4. Jahrhundert v. Chr. SBL Biblical Encyclopedia Series, 8 (Atlanta: SBL).

Gosse, B. 2004. "Le Psautier, Jr 9,1-8, et le livre de Jérémie," Old Testament Essays 17/1, 58-77.

_L'influence du livre des Proverbes sur les rédactions bibliques à l'époque perse (Paris: Gabalda).

Hossfeld, F-L. and Zenger, E. 2005. Psalms 2: A Commentary on Psalms $51-$ 100. Ed. Klaus Baltzer; Tr. Linda M. Maloney. Hermeneia (Minneapolis: Fortress Press).

2002. Die Psalmen: Psalm 51-100. Kommentar zum Alten Testament (Würzburg: Echter).

Johnson, V. 2009. David in Distress: His Portrait through the Historical Psalms. Library of Hebrew Bible/Old Testament Studies 505 (New York, London: T \& T Clark).

Köhler, L. and Baumgartner, W. 1994. The Hebrew and Aramaic Lexicon of the Old Testament. Edited by Johann Jakob Stamm, translated by M. E. J. Richardson. CD-ROM ed. (Leiden: Brill).

Kraus, H-J. 1978. Psalmen 1-59. Biblischer Kommentar Altes Testament; 5. Auflage (Neukirchen: Neukirchener). 
Kselman, J.S. and Barré, M.L. 1998. "Psalm 55: Problems and Proposals," Catholic Biblical Quarterly 60, 440-462.

Pohlmann, K-F. 1989. Die Ferne Gottes - Studien zum Jeremiahbuch: Beiträge zu den "Konfessionen" im Jeremiabuch und ein Versuch zur Frage nach den Anfängen der Jeremiatradition. Beiheft zur Zeitschrift für die alttestamentliche Wissenschaft 179 (Berlin / New York: Walter de Gruyter).

Schmidt, W.H. 2008. Das Buch Jeremia, Kapitel 1-20. Das Alte Testament Deutsch, 20 (Göttingen: Vandenhoeck \& Ruprecht).

Seybold, K. 1996. Die Psalmen. Handbuch zum Alten Testament, I/15 (Tübingen: J. C. B. Mohr [Paul Siebeck]).

Tate, M.E. 1990. Psalms 51-100. Word Biblical Commentary, 20 (Dallas: Word Books).

Terrien, S. 2003. The Psalms. Strophic Structure and Theological Commentary. The Eerdmans Critical Commentary (Grand Rapids, Michigan / Cambridge, U.K.: Eerdmans).

The NET Bible, Version 1.0 Copyright (C) 2004, 2005 Biblical Studies Foundation. Electronic copy.

Van der Lugt, P. 2010. Cantos and Strophes in Biblical Hebrew Poetry II. Psalms 42-89 (Leiden: Brill).

Weber, B. 2014. “'An dem Tag, als JHWH ihn rettete aus der Hand aller seiener Feinde und aus der Hand Sauls' (Ps 18,1): Erwägungen zur Anordnung der biographischen Angaben zu David im Psalter," Vetus Testamentum 64, 284-304.

2005 "Zum sogenannten 'Stimmungsumschwung' in Psalm 13." Pages 116-138 in P.W. Flint and P.D. Miller (eds.), The Book of Psalms: Composition and Reception, Supplements to Vetus Testamentum (Leiden / Boston: Brill).

2001. Werkbuch Psalmen I: Die Psalmen 1 bis 72 (Stuttgart: Kohlhammer).

Zenger, E. (ed.) 2010. The Composition of the Book of Psalms. Bibliotheca Ephemeridum Theologicarum Lovaniensium 238 (Leuven / Paris / Walpole, MA). 